\title{
Filgrastim-primed Peripheral Blood Progenitor Cells
}

National Cancer Institute

\section{Source}

National Cancer Institute. Filgrastim-primed Peripheral Blood Progenitor Cells. NCI

Thesaurus. Code C98836.

Peripheral blood progenitor cells (PBPC) primed with a recombinant form of the human granulocyte colony-stimulating factor (filgrastim). As a hematopoietic growth factor, filgrastim is able to mobilize hematopoietic progenitor cells (HPCs) into the peripheral blood which allows for an increased number of HPCs upon collection by leukapheresis. Administration of filgrastim-primed PBPCs following hematopoietic stem cell transplantation provides increased numbers of progenitor cells which may prevent pancytopenia and relapse. 